\title{
Teat Obstruction in Cows - A Clinical Study under Conventional Milking System
}

\author{
B. Udayakumari*, T. P. Balagopalan, N. Aruljothi and B. Ramesh Kumar \\ Department of Veterinary Surgery and Radiology, Rajiv Gandhi Institute of Veterinary \\ Education and Research, Puducherry-605 009, India \\ *Corresponding author
}

\begin{tabular}{l} 
Ke y w o r d s \\
Teat obstruction, \\
Covered teat lesions \\
\hline Article Info \\
\hline $\begin{array}{l}\text { Accepted: } \\
\text { 05 February } 2020 \\
\text { Available Online: } \\
\text { 10 March } 2020\end{array}$ \\
\hline
\end{tabular}

\section{A B S T R A C T}

The present study was done on eighteen cows with a history of milk flow disorders under conventional milking pattern, divided into 3 groups of 6 animals each based on the type of obstructive lesion viz; focal (TypeI), Diffuse (Type II) and membranous (Type III) respectively. Out of 18 cows 17 were crossbred jersey and one was crossbred Holstein Friesian aged between 3.5-7 years presented during $2^{\text {nd }}-4^{\text {th }}$ lactation and maintained with calves alive and all were suckling except one. In the present study, teat obstruction was noticed predominantly on right fore teat. More than $50 \%$ of the affected teats were cylindrical in shape and hard in consistency. The teat end shape noticed in the affected teat was round. The length of the teat cistern on probing ranged from $3.2-8.6 \mathrm{~cm}$.

\section{Introduction}

The conformation of mammary system such as changes in the teat tissue by milking, teat canal integrity and teat tissue pliability had a significant impact on the risk of teat lesions, (Neijenhuis et al., 2001). A protocol for systematic evaluation of teat condition linked with production in commercial herds was proposed by Mein et al., (2001) and Prasad et al., (2010). Reports on reliability of such methods for evaluation of teat with milk flow disorders under conventional milking pattern are scanty. The present study describes the clinical examination of the teat with teat obstructions in cows under conventional milking pattern.

\section{Materials and Methods}

Eighteen cows (18 teats) irrespective of age, breed and parity presented with a history of milk flow disorders by hand milking to the large animal surgical ward of the Teaching Veterinary Clinical campus, Rajiv Gandhi Institute of Veterinary Education and 
Research and diagnosed to have obstructive lesions in the teat cistern above the streak canal were selected for the present study. These animals were randomly divided into 3 groups of 6 animals each. Animals showing type I lesions (Focal teat obstruction $<30 \%$ mucosa) were allotted to group I (IA - IF), type II lesions (Diffused teat obstruction > $30 \%$ mucosa) to group II (IIA - IIF) and type III lesions (Membranous lesion separating the gland and teat cistern) to group III (IIIA-IIIF). All the cows were subjected to clinical examination of the affected teat were performed.

Clinical examination as described by Ovesen (1992) and Prasad et al., (2010) of the affected teat and that of the apparently contralateral teat were performed preoperatively, and on $15^{\text {th }}$ and $30^{\text {th }}$ day postoperatively. The parameters were as follows:

\section{Teat which is affected}

Shape of the teat - (Bottle/ Funnel/ Cylindrical/ Cone/ Pear)

Skin color of teat - Brown (normal) / Pink or reddish (congested or irritation) / cyanotic or purplish (lack of blood or oxygen).

Texture of the teat skin- Smooth sheen, soft, healthy skin (normal), scaly, flaky or rough skin but with no crackling (dry).

Consistency of the teat - Soft or hard.

\section{External lesions/ Palpable internal lesion if any}

Nature of the teat orifice - The nature of the teat orifice was scored as NR (No ring, a typical status for many teats soon after the start of lactation, smooth or slightly rough ring), $\mathrm{S}$ ( A raised ring with no roughness or only mild roughness and no keratin fronds), $\mathrm{R}$
( A raised roughened ring with isolated fronds of old keratin extending $1-3 \mathrm{~mm}$ from the orifice), and VR (A raised ring with very rough fronds of old keratin extending $>4 \mathrm{~mm}$ from the orifice, open lesions or scab formation).

Teat-end shape - The teat end shape was categorized as pointed, round, flat, disk, inverted, pointed disk, round flat, and round.

Patency of the teat cistern - Patency of the teat cistern assessed by hand milking and noted as fully patent/ partially patent/ nonpatent.

Length of the teat cistern (cm) - The length of the teat cistern was measured by probing the teat cistern through the teat orifice.

\section{Results and Discussion}

All the cows except one were crossbred jersey, where it was crossbred Holstein Fresian among the 18 cows. The age of the animals was between 4.5-5 years, 5-7 years and 3.5-6 years in group I, II and III respectively. The present findings were in agreement with that reported by Aruljothi et al., (2009) who stated that crossbred jersey/ Holstein Fresian cows aged 2-9 years were found to be more prone to teat obstruction. However, Bhatt et al., (2010) reported that the incidence of milk flow disorder was more in 6-10 years old animals. They were presented during their $2^{\text {nd }}$ lactation in 14 cows, $3^{\text {rd }}$ lactation in 2 cows and $4^{\text {th }}$ lactation in 2 cows. All the cows were cross bred, high yielders, in early period of $2-4^{\text {th }}$ lactation and well maintained. The period of occurrence indicated that the structural changes which led to milk flow disorders might have occurred during the dry period. The condition might have worsened by the stress due to suckling, Milking pattern and delay in getting proper treatment. According to Sharma et al., (2005) 
and Aruljothi et al., (2009), the incidence of teat affections was relatively high in animals during their first and third lactation respectively. All the cows except one were maintained with calves alive at an age group between 9-17, 9-15 and 5-60 days old in group I, II and III respectively and all were suckling. Similar observations had been made earlier by Aruljothi et al., (2009) who reported about $94 \%$ of the animals with teat obstruction were having suckling calves.

The observation on clinical examination of the affected teats shown in the figures (1-18).

In group I, the right hind teat, left fore teat and left hind teat was found to be affected equally ( 2 cows each). In group II, the right fore teat in 3 cows followed by right hind teat ( 2 cows) and left fore teat (one cow). I group III, right fore teat in 3 cows followed by left fore ( 2 cows) and left hind teat (one cow). In the present study, right fore teat was found to be affected more in six cows (33\%) followed by left fore teat in 5 cows (28\%), right hind teat in 4 cows $(22 \%)$ and left hind teat in 3 cows (17\%). However, Agger and Hesselholt, (1986) and Sharma et al., (2005) observed left hind teat as the most affected one.

In group I, the shape of the affected teats was cylindrical in 5 cows and funnel in 1 cow. In group II, it was cylindrical in all the cows. In group III, the shape of the affected teat was cylindrical in 4 cows and that of funnel in 2 cows. In this study, the shape of the affected teat was cylindrical in 15 cows $(83 \%)$ and funnel in three cows (17\%). Uddin et al., (2009) defined various teat shapes and teatend shapes in indigenous and crossbred animals. Sutradhar (1999) and Prasad et al., (2010) and Porcionata et al., (2010) noted that both cylindrical and funnel shaped teats may yield more average milk compared to other types which indicated that the shape of the teat may be a contributory factor for milk flow disorders in cows.
The skin color of the affected teats was brown (normal) in all the eighteen cows. The texture of the skin was smooth in all the eighteen cows. The study showed that there is no abnormality found as for as the skin color and texture of the teat is concerned with teat obstruction.

In group I, the consistency of the teats was hard in 5 cows and in one it was soft in nature. In group II, the consistency was hard in 3 cows and in other 3 it was soft in nature. In group III, it was hard in 4 cows and in 2 it was soft in nature. So, the consistency of the teat with obstruction was hard in $12(67 \%)$ and soft in 6 affected teats (33\%). Aruljothi et al., (2009) observed hardness on palpation of teat with obstruction preoperatively.

There was no external lesion noticed on all the eighteen affected teats which deleted the role of environmental factors causing teat obstruction.

In group I, the internal palpable lesions could be noticed at the base in 5 cows and at mid teat in 1 cow. In group II, it was observed at the base in 4 cows and at mid teat in 2 cows. In group III, the internal palpable lesions could be noticed at the base in 5 cows and at mid teat in 1 cow. There was visible swelling on the external surface of the teat at the site of palpable internal lesion at the base in 14 cows (78\%) and at the mid teat in 4 cows $(22 \%)$. It may be due to the local tissue response to the irritation at the site of obstruction while milking or suckling.

The teat orifice was not having ring formation in all the eighteen affected teats which was a common feature in cows with machine milking as reported by Chrystal et al., (1999).

In group I, the teat-end shape was round in 3 cows, pointed in 2 and round flat in one. In group II, it was round in $1 \mathrm{cow}$, pointed in 2 cows, round flat in 1 cow and pointed-disk in 
2 cows. In group III, it was round in 3 cows, pointed in 1 , pointed disk in 1 and round flat in one. In this study, the teat-end shape was round in 7 teats $(39 \%)$, pointed in $5(28 \%)$, round flat (17\%) and pointed disk (17\%) in 3 each of the affected teats. Ovesen (1992) reported that average rate of milk flow was significantly higher for teats with flat and concave tips than for cows with pointed and round teat ends. Since the milk flow rate was comparatively less in the teats having the teatend shapes as observed in the affected animals, it was understood that the teats might have undergone heavy stress while milking for evacuating the quarter fully. This type of conformation of mammary system has a significant impact on the risk of teat lesions increasing the stress on teat tissue while milking (Mein et al., 2001).

\section{Observations on Clinical Examination of The Affected teat in Group I Animals}

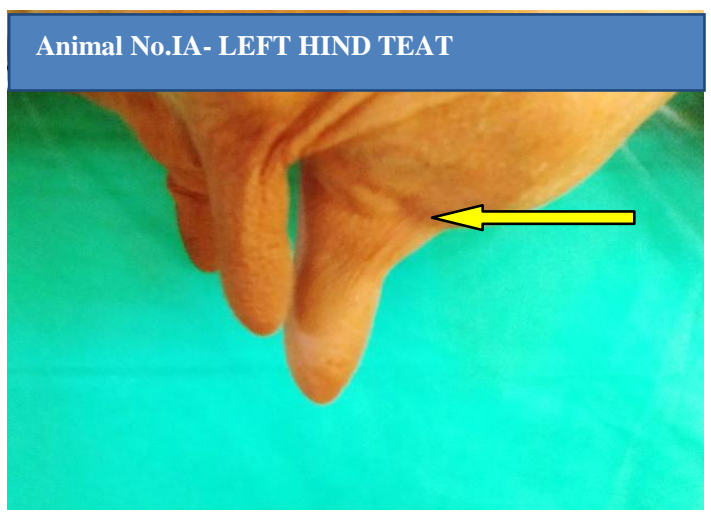

Fig 1. Funnel shaped teat with pointed teat end showing swelling at the base

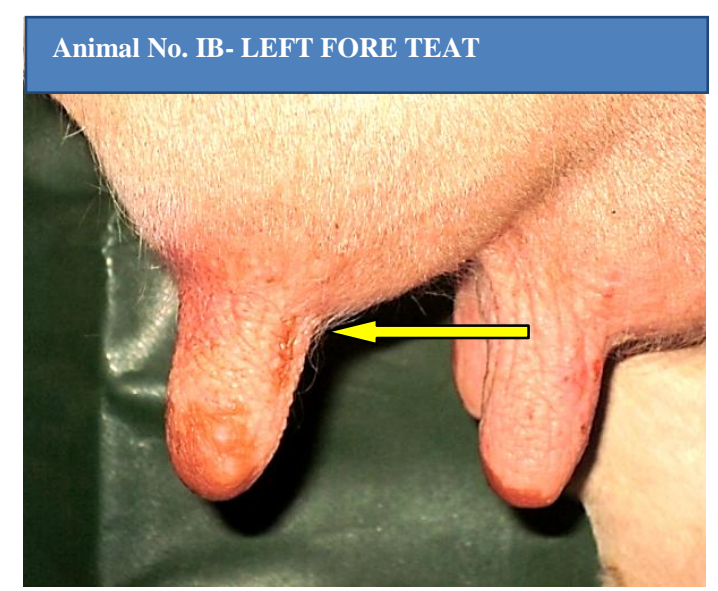

Fig 2. Cylindrical shaped teat with round teat end showing swelling at the base

\section{Animal No.IC - LEFT HIND TEAT}




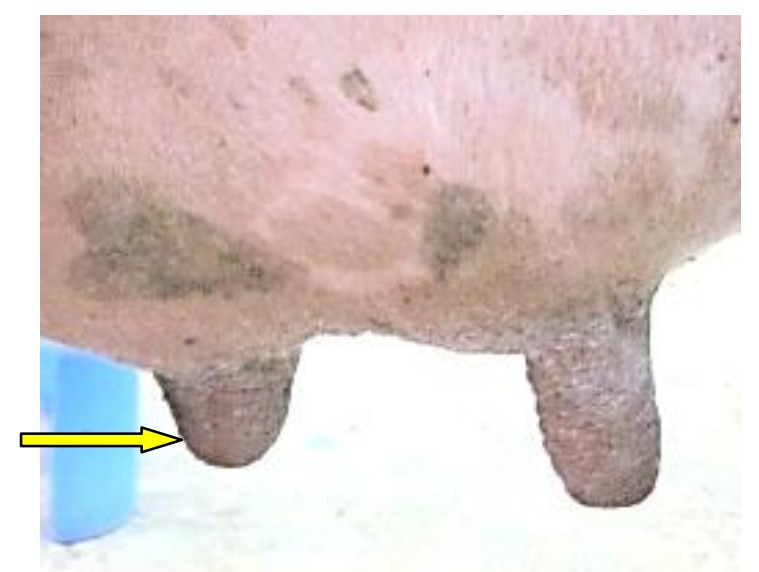

Fig 3. Cylindrical shaped teat with round flat teat end showing swelling at the base

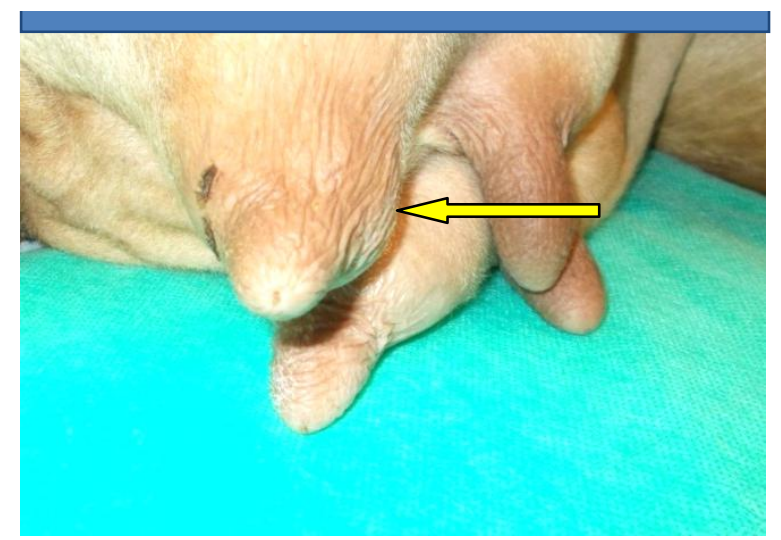

Fig 4. Cylindrical shaped teat and round teat end showing swelling at the base

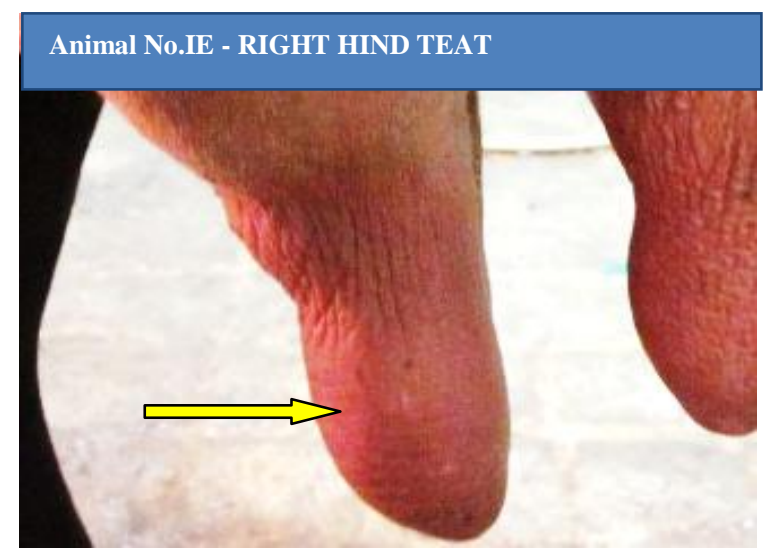

Fig 5. Cylindrical shaped teat and pointed teat end showing swelling at the mid teat 


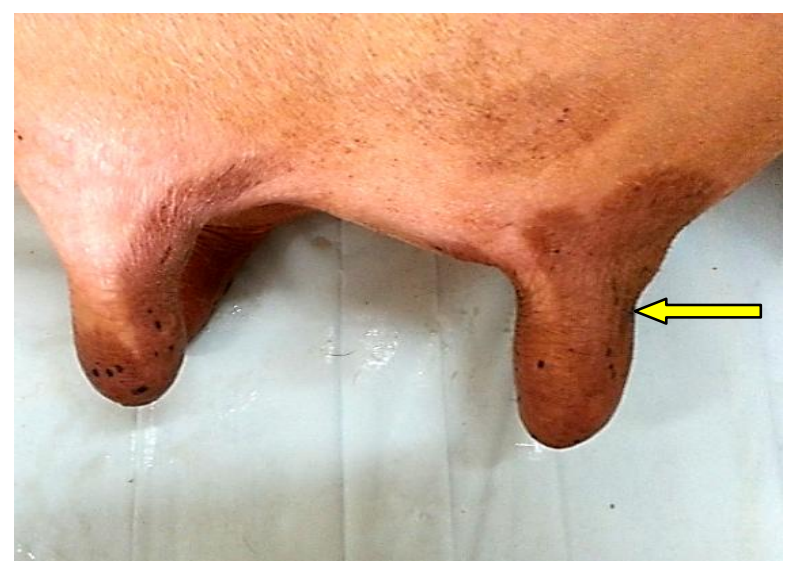

Fig 6. Cylindrical shaped teat with round teat end showing swelling at the base

\section{OBSERVATIONS UN CLINICAL EXAMINA'IUN UH' IHE AFHECTED TEAT OF ANIMALS IN GROUP II}

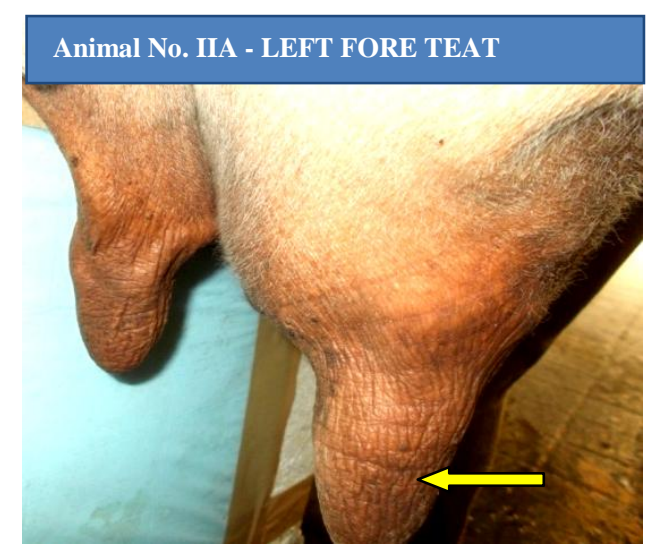

Fig 7: Cylindrical shaped teat and pointed teat end showing swelling at the mid teat

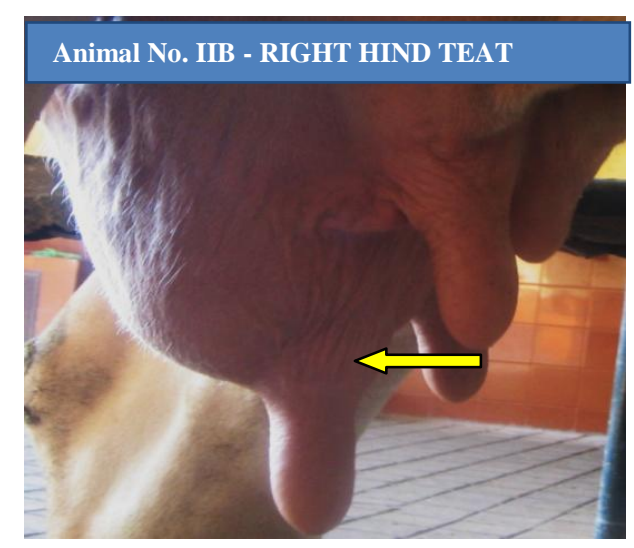

Fig 8: Cylindrical shaped teat with pointed disk teat end showing swelling at the base 


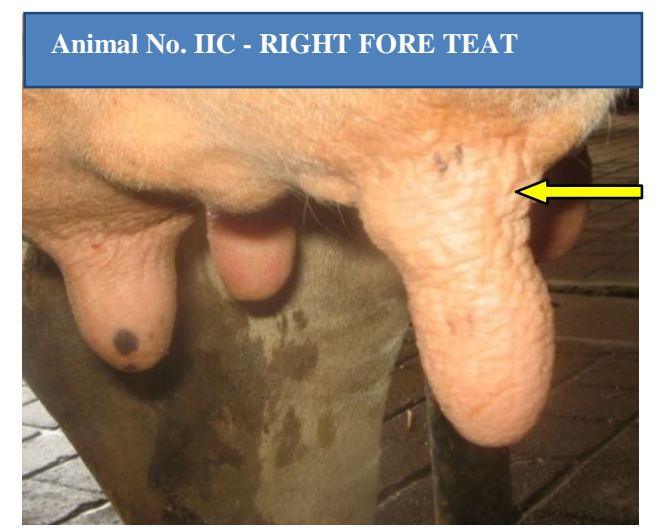

Fig 9: Cylindrical shaped teat with round teat end showing swelling at the base

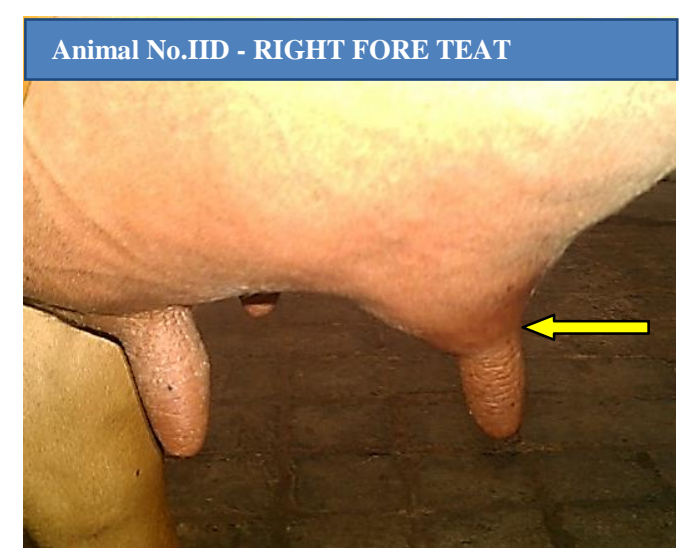

Fig 10: Cylindrical shaped teat with round flat teat end showing swelling at the base

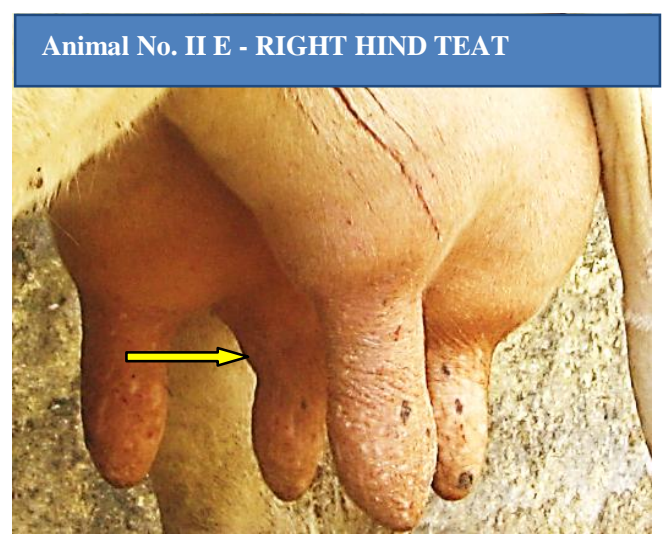

Fig 11: Cylindrical shaped teat with pointed teat end showing swelling at the base 


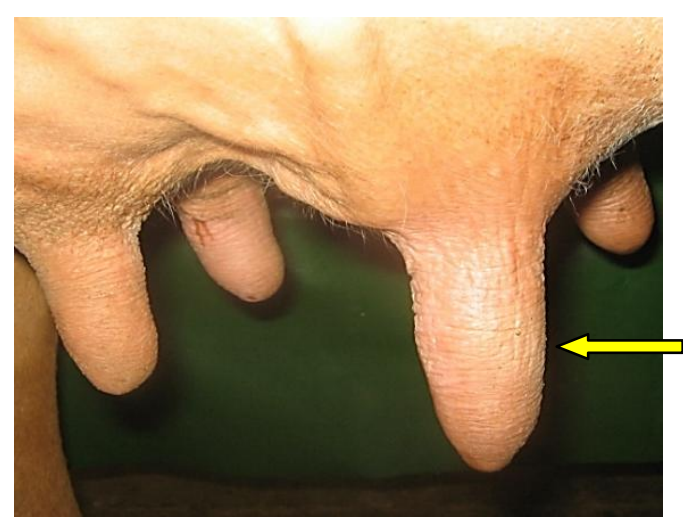

Fig 12: Cylindrical shaped teat with pointed disk teat end showing swelling at the mid teat

\section{OBSERVATIONS ON CLINICAL EXAMINATION OF THE AFFECTED TEAT OF} ANIMALS IN GROUP III

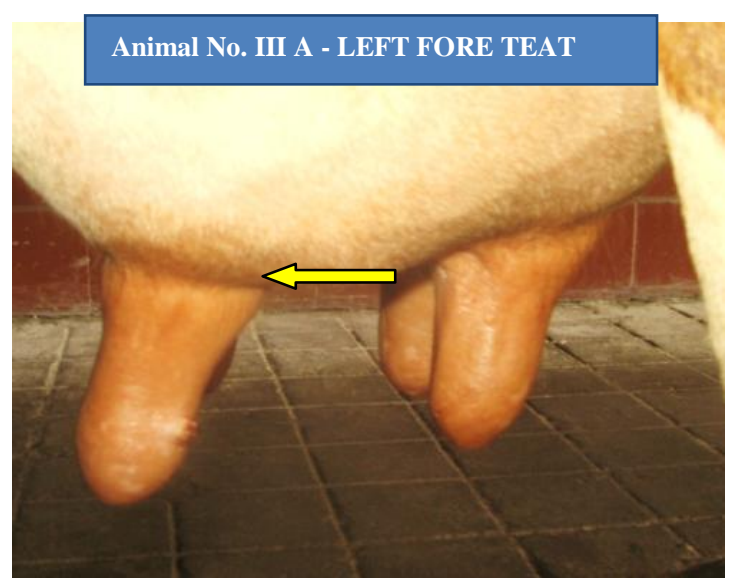

Fig 13. Cylindrical shaped teat with pointed teat end showing swelling at the base

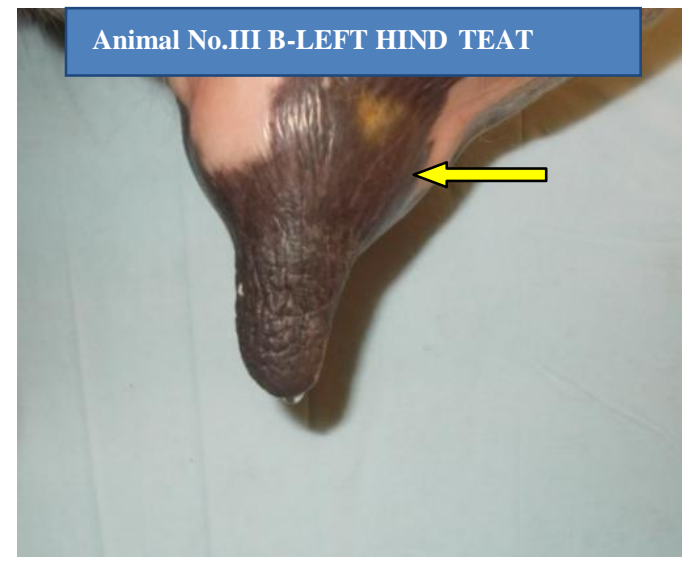

Fig 14. Funnel shaped teat with round teat end showing swelling at the base 


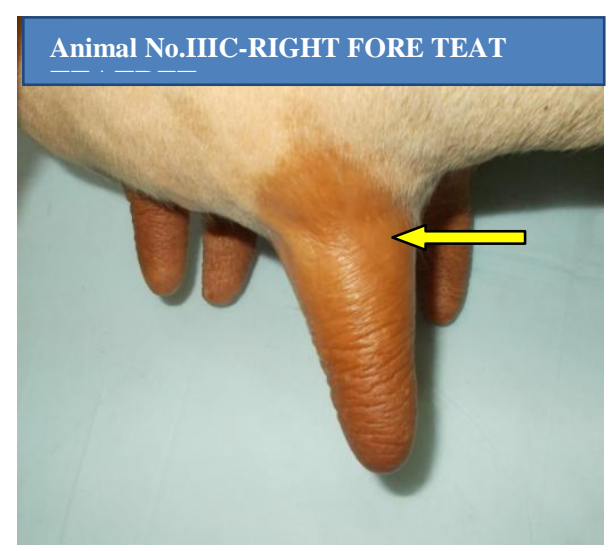

Fig 15. Funnel shaped teat with round teat end showing swelling at the base

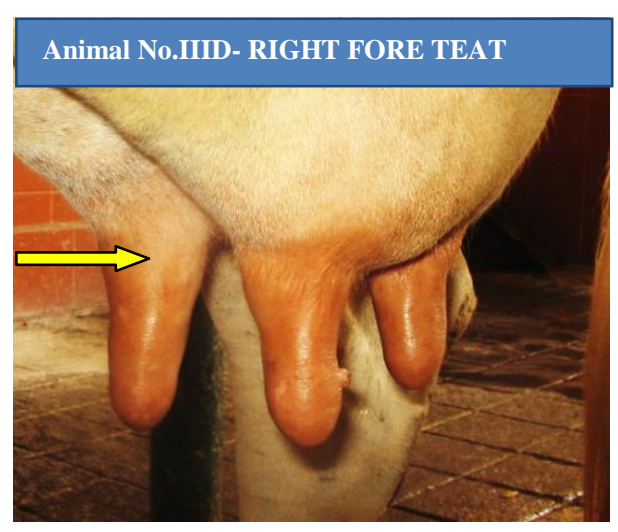

Fig 16. Cylindrical shaped teat with round flat teat end showing swelling at the base

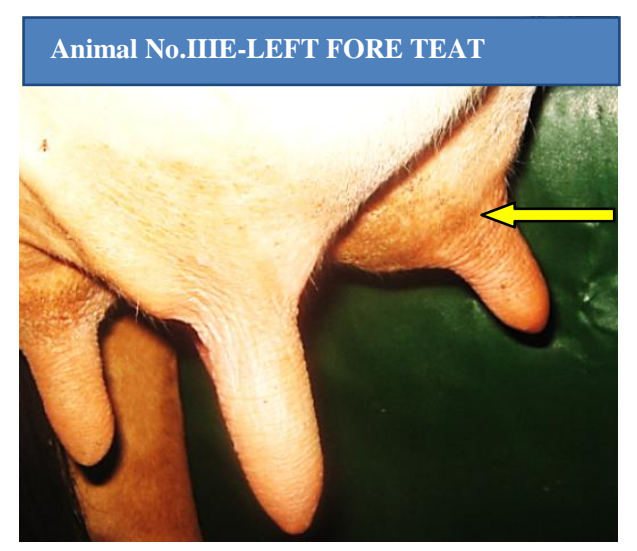

Fig 17. Cylindrical shaped teat with pointed disk teat end showing swelling at the base 


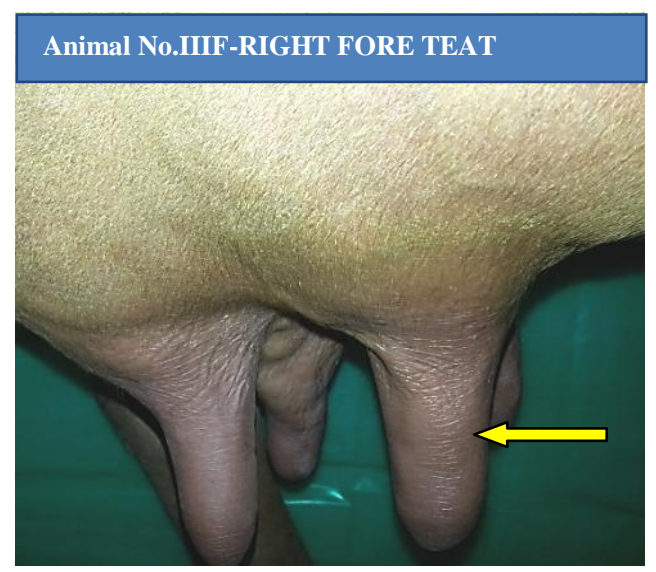

Fig 18.Cylindrical shaped teat with round teat end showing swelling at the mid teat

Since it was internal type of teat lesion the teat cistern was non-patent in all the eighteen affected teats. The length of the teat cistern upon probing was ranging from 4.8-7.2, 3.28.6 and $5.0-7.2 \mathrm{~cm}$ in group I, II and III respectively. Probing of the teat cistern was useful to detect the level of obstruction and the consistency of the obstructive lesion. The increased length noticed in group III may be due to the flexibility of membraneous septum.

It is concluded, even though there was paucity of data regarding skin color, texture and nature of teat orifice, the observations on teat shape, teat-end shape, visible and palpable lesions and character of teat cistern proves that the conformation of mammary system had a significant impact on the risk of teat lesions as suggested by Mein et al., (2001).

\section{References}

Agger, J.F., and Hesselholt, M., 1986. Epidemiology of teat lesions in a dairy herd. I: Description of the incidence, location and clinical appearance. Nord. Vet. Med., 38: 209-19.

Aruljothi, N., Balagopalan, T.P., Antony, P.X., Kumar, R., and Rameshkumar, B., 2009. Teat obstruction in cows. Indian Vet. J., 86: 840-842.
Bhatt, S.M., Parikh, P.V., Patil, D.B., Kelawala, N.H., Jhala, S.K., Joy, N., and Dar, M.U.D., 2010. Incidence and surgical management of milk flow disorders in dairy animals. Intas Polivet, 11: 39-40.

Chrystal, M.A., Seykora, A.J., and. Hansen, L.B., 1999. Genetics and breeding heritabilities of teat end shape and teat diameter and their relationships with somatic cell score. J. Dairy Sci., 82: 2017-2022.

Mein, G.A., Neijenhuis, F., Morgan, W.F., Reinemann, D.J., Hillerton, J.E., Baines, J.R., Ohnstad, I., Rasmussen, M.D., Timms, L., Britt, J.S., Farnsworth, R. and Cook, N.B., 2001. Evaluation of bovine teat condition in commercial dairy herds: 1. Non infectious factors. Proceedings of $2^{\text {nd }}$ AABP-NMC International symposium on mastitis and milk quality, Canada.

Neijenhuis, F., Klungel, G.H., and Hogeveen, H., 2001. Recovery of cow teats after milking as determined by ultrasonographic scanning. J. Dairy Sci., 84: 2599-2606.

Ovesen, E., 1992. Milking ability in relation to size and shape of teats. Anim Prod., 15: 251-257.

Porcionata, M.A.F., Soares, W.V.B., Reis, 
C.B.M., Cortinhas, C.S., Mestieri, L., and Santos, M.V., 2010. Milk flow, teat morphology and subclinical mastitis prevalence in Gir cows. Pesq. Agropec. Bras., 45: 1507-1512.

Prasad, R.M.V., Sudhakar, K., Raghava Rao, E., Ramesh Gupta, B., and Mahender, M., 2010. Part of the Ph.D thesis submitted by the First author to SVVU, Tirupathi.

Sharma, S., Singh, K.B., Bansal, B.K., and Sharma, D.K., 2005. Clinical symptomatology and epidemilogical observations on teat skin lesions in buffaloes. Buffalo B., 24: 12-16.

Sutradhar, S., 1999. Morphological relationship of udder and teats with mastitis and milk yield of crossbred dairy cows. MS Thesis. Department of surgery and Obstetrics, Faculty of Veterinary Science, Bangladesh Agricultural University, Mymensingh. 93.

Uddin, M.A., Karnal, M.M., and Haque, M.E., 2009. Epidemiological study of udder and teat diseases in dairy cows. Bangl. J. Vet. Med., 7: 332-340.

\section{How to cite this article:}

Udayakumari, B., T. P. Balagopalan, N. Aruljothi and Ramesh Kumar, B. 2020. Teat Obstruction in Cows - A Clinical Study under Conventional Milking System. Int.J.Curr.Microbiol.App.Sci. 9(03): 1261-1271. doi: https://doi.org/10.20546/ijcmas.2020.903.146 